\title{
Mineralogical controls on mobility of rare earth elements in acid mine drainage environments
}

\author{
T.O. Soyol-Erdene ${ }^{\text {a, b }}$, T. Valente ${ }^{\text {a, }{ }^{*}, \text { J.A. Grande }}{ }^{\text {, }}$, M.L. de la Torre ${ }^{c}$ \\ a Institute of Earth Sciences, Pole of the University of Minho, Campus de Gualtar, 4710-057 Braga, Portugal \\ b Department of Environmental and Forest Engineering, School of Engineering and Applied Sciences, National University of Mongolia, Ulaanbaatar 14201, \\ Mongolia \\ c Escuela Técnica Superior de Ingeniería, University of Huelva, Campus de la Rábida, Huelva, Spain
}

\section{H I G H L I G H T S}

- REE in river waters, acid mine waters, AMD-precipitates from Iberian Pyrite Belt.

- Description of overall fractionation of REE during water-mineral interaction.

- Capability of REE to be released or sequestered by different AMD-precipitates.

- Dissolution of precipitates has significant contribution on REE distribution in AMD.

- Highest REE retention in $\mathrm{Al}$ and $\mathrm{Mg}$ (pickeringite, epsomite or hexahydrite) sulfates.

\section{A R T I C L E I N F O}

\section{Article history:}

Received 11 January 2018

Received in revised form

26 March 2018

Accepted 16 April 2018

Available online 17 April 2018

Handling Editor: Martine Leermakers

\section{Keywords:}

Acid mine drainage (AMD)

Water-mineral interaction

Al-Mg sulfates

Rare earth elements

NASC normalized pattern

\begin{abstract}
A B S T R A C T
Rare earth elements (REE) were analyzed in river waters, acid mine waters, and extracts of secondary precipitates collected in the Iberian Pyrite Belt. The obtained concentrations of the REE in river water and mine waters (acid mine drainage - AMD) were in the range of $0.57 \mu \mathrm{g} / \mathrm{L}(\mathrm{Lu})$ and $2579 \mu \mathrm{g} / \mathrm{L}(\mathrm{Ce})$, which is higher than previously reported in surface waters from the Iberian Pyrite Belt, but are comparable with previous findings from AMD worldwide. Total REE concentrations in river waters were ranged between $297 \mu \mathrm{g} / \mathrm{L}$ (Cobica River) and $7032 \mu \mathrm{g} / \mathrm{L}$ (Trimpancho River) with an average of $2468 \mu \mathrm{g} / \mathrm{L}$. NASC (North American Shale Composite) normalized REE patterns for river and acid mine waters show clear convex curvatures in middle-REE (MREE) with respect to light- and heavy-REE.

During the dissolution experiments of AMD-precipitates, heavy-REE and middle-REE generate the most enriched patterns in the solution. A small number of precipitates did not display MREE enrichment (an index $\mathrm{Gd}_{\mathrm{n}} / \mathrm{Lu}_{\mathrm{n}}<1.0$ ) in NASC normalized pattern and produced relatively lower REE concentrations in extracts. Additionally, very few samples, which mainly contained aluminum sulfates, e.g., pickeringite and alunogen, displayed light-REE enrichment relative to heavy-REE (HREE). In general, the highest retention of REE occurs in samples enriched in magnesium (epsomite or hexahydrite) and aluminum sulfates, mainly pickeringite.
\end{abstract}

(c) 2018 Elsevier Ltd. All rights reserved.

\section{Introduction}

Rare earth elements (REE) are powerful tracer for environmental studies due to their very similar geochemical behavior (Elderfield et al., 1990). Their fractionation pattern can provide useful information on detection of mining impacts. Also, they can be used as tracer on monitoring fate and transport of pollutants in

\footnotetext{
* Corresponding author.

E-mail address: teresav@dct.uminho.pt (T. Valente).
}

the environment (Merten et al., 2005; Olías et al., 2005; PérezLópez et al., 2010; López-González et al., 2012; Lecomte et al., 2017). Concentrations and distribution (pattern) of REE in water systems are determined by a complexity of factors, such as REE source, fractionation within the series during water-rock or watercolloid interaction, aqueous processes such as adsorption and desorption, and chemical composition of water, including $\mathrm{pH}$ and concentration of available ligands (Elderfield et al., 1990; Welch et al., 2009). Previous studies have revealed that acidic waters have significantly higher concentrations of dissolved REE rather 
than fresh non-acidic surface waters. Specifically, acid mine drainage (AMD) waters are known by their high contents of REE, in the range of hundreds to thousands $\mu \mathrm{g} / \mathrm{L}$ (Verplanck et al., 2001; Borrego et al., 2012). Moreover, Nordstrom (2011) refers AMD as the most important process, promoting remobilization of the REE from host rocks. In this context, Migaszewski et al. (2016) obtained REE contents of $6288 \mu \mathrm{g} / \mathrm{L}$ in seeps that drain mine tailings in the Wiśniówka mining area (south-central Poland), considering them the most distinctive REE-rich AMD surface waters across the world. Generally these mine waters show enrichment of middle rare earths (MREE) relative to the light rare earths (LREE) and heavy rare earths (HREE) when normalize to Earth surface reservoirs (Olías et al., 2005; Grawunder et al., 2014; Migaszewski and Gałuszca, 2015). However, MREE enrichment is observed also for non-acidic waters containing high concentrations of organic matter and colloids (Leybourne and Johannesson, 2008). Thus, controlling factors for MREE enrichment relative to LREE and HREE in acidic waters (e.g., acid mine drainage) are not fully understood. Additionally, there is still doubt that MREE enrichment pattern is not common to acidic environment (Leybourne and Johannesson, 2008), nor it is always generated in acidic solution (Welch et al., 2009 and the references therein; Prudêncio et al., 2015). The study by Welch et al. (2009) found that dissolution of sulfide bearing materials creates MREE enrichment in solution even though their own composition have LREE enriched pattern. MREE enriched signature in solution presumably results from a fractionation through REE series in acidic condition (Elderfield et al., 1990; Welch et al., 2009; Pérez-López et al., 2010).

This work is focused on studying REE patterns and concentrations in river waters, mine waters, and water extracts of secondary precipitates (denominated AMD-precipitates) collected in the Spanish sector of the Iberian Pyrite Belt (SW Spain). The main aims are the following; 1) to evaluate impact of formation and dissolution processes of AMD-precipitates on riverine REE geochemistry; 2) to describe overall fractionation of REE during water-mineral interaction; 3) to study capability of different AMD-precipitates for REE release and sequestration.

\section{Site description}

\subsection{Geology and climate}

The Iberian Pyrite Belt (IPB) extends from north of Seville - in Spain - to southern of Portugal, constituting a region known for its large massive sulfide ore deposits (Sáez et al., 1999). From the geological point of view, the IPB is located in the Iberian Massif (Fig. 1-A), where two zones can be differentiated: the South Portuguese Zone (SPZ) in the south, and the Ossa-Morena Zone in the north. In the southern part, sediment from the deposits of the Guadalquivir basin crops out. The Iberian Pyrite Belt is in the central zone of the SPZ and is formed by igneous and Palaeozoic sedimentary rocks (Antunes et al., 2010). These crop out as a strip almost $50 \mathrm{~km}$ wide and $230 \mathrm{~km}$ long. It contains large volcanichosted massive deposit of pyrite and polymetallic sulfides (particularly of $\mathrm{Cu}, \mathrm{Pb}$, and $\mathrm{Zn}$ ).

The sulfides mineralization is mainly represented by massive pyrite, followed by chalcopyrite, sphalerite, and galena. Textural characteristics of sulfides are variable, but most of the massive sulfides are monotonous fine grained pyrite, often framboidal and colloform. The grains are usually fractured and brecciated (Tornos et al., 2008), which promotes reactivity and enhances dissolution. Gangue includes abundant quartz and aluminum silicates (mainly chlorite), with minor amounts of carbonates. More detailed information about mineralogy and geochemistry of the Iberian Pyrite Belt are provided by several authors (e.g., García de Miguel, 1990;
Velasco et al., 1998; Sáez et al., 1999; Sánchez-España et al., 2000; Tornos et al., 2008; Conde et al., 2009; Mantero et al., 2011).

The study area, in the Huelva province, has a Mediterranean climate, which can be classified as semi-arid, due to low precipitation rates. Annual precipitation is about $630 \mathrm{~mm} / \mathrm{year}$, being mostly concentrated in the wet season from October to May. Monthly precipitation ranges from 3 to $121 \mathrm{~mm}$, corresponding to June and December, respectively. Average annual temperature is $17.1^{\circ} \mathrm{C}$, January being the coldest month (mean $9.8^{\circ} \mathrm{C}$ ), while in the summer, July and August have the highest temperatures (mean $25.7^{\circ} \mathrm{C}$ ) (Instituto Nacional de Meteorología; unpublished data). More detailed climate data can be provided by Valente et al. (2016a). The measured humidity variation, in the interval between approximately $25 \%$ and $50 \%$, is controlled by local hydrological conditions instead of seasonal fluctuations.

\subsection{Mining and environmental framework}

The incessant mining activity, since Roman times, led to numerous abandoned and active mining works that are an important source of acid, sulfates, and heavy metals. Nowadays, there are more than 4800 ha occupied by waste dumps, open pits, tailing dams, and mining facilities, corresponding to 88 sulfide mines (Grande et al., 2013). Among the multitude of mines, some of them can be considered representative of the paragenetic diversity as well as of mining history and environmental framework of the IPB, such as Riotinto, Tharsis, San Telmo, Herrerías, and Lagunazo.

Most of the mines were closed without environmental guidelines and without preventive or corrective measures to protect the environment. Therefore, they continue to mobilizing high amounts of acidity, sulfates, metals, and metalloids. The leachates emerging from waste dumps, tailing dams, and other mining facilities are discharged into the river network, being responsible for the contamination of the receiving watercourses (Valente et al., 2013).

\section{Methods}

\subsection{Mineral sampling and analysis}

The sampling campaign was performed under strong evaporation and low flow hydrological conditions (July 2015). The field measurements of temperature and relative humidity in the sampling areas gave relatively constant values throughout at least three weeks during sampling.

Fig. 1-B represents the configuration of the river network studied in this work. The present research was focused on the entire Spanish sector of the Iberian Pyrite Belt, covering different environments. One refers to waste-dumps, seepages, and leachates in five abandoned mines. This represents proximal conditions, i.e. near the sulfides sources. The other environment corresponds to the receiving river network, therefore representing distal conditions. For this last, eight sampling areas were established, in order to characterize the sub-basins defined in the IPB by Ostale (2014) (Fig. 1-B). So, there are samples of secondary precipitates from contaminated rivers and from selected representative mines. The following abandoned mines were designated in order to represent the diversity of the main sources of AMD: Riotinto, Tharsis, Lagunazo, San Telmo, and Herrerías. In turn, the receiving river network comprises eight major rivers: Trimpancho, Cobica, Meca, Oraque, Olivargas, Odiel, Tinto, and Guadiamar (Fig. 1-B).

At each sampling area there were a variable number of samples, which were meant to cover the diversity observed in the field on the basis of macroscopic properties. Occurrence modes, color, and texture were used to define this diversity. In the mining areas, samples were collected from outcrops, in exposed rocks or in 


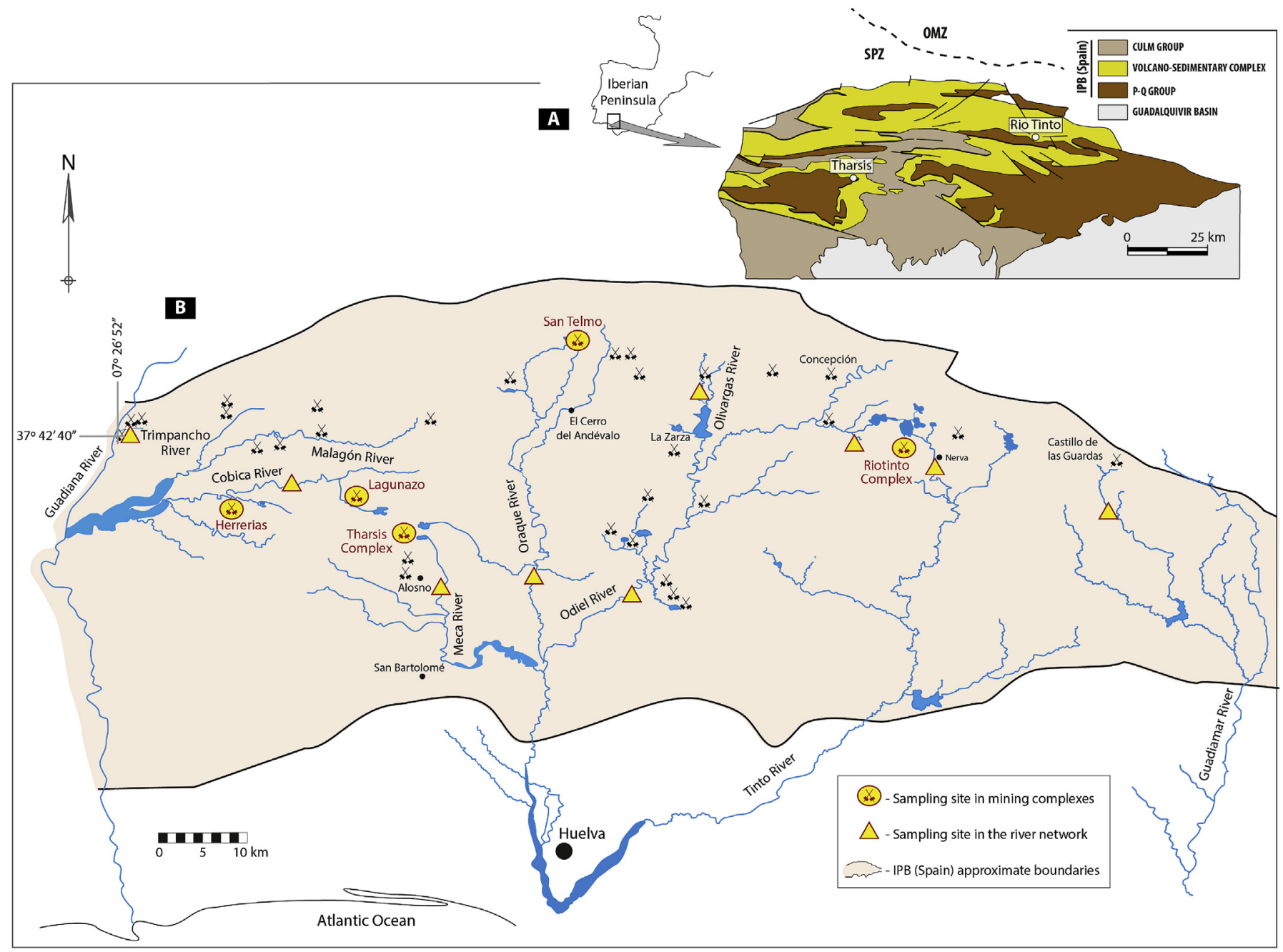

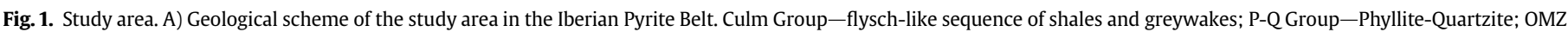
- Ossa Morena Zone; SPZ - South Portuguese Zone. B) River network of the Spanish sector of the Iberian Pyrite Belt with sampling sites for water and AMD-precipitates.

fractures and cavities. Also, sampling was focused on the surface of the piles, and in drainage channels. On the receiving watercourses, samples were collected in the dry banks, exposed rocks, and rivers shores. In summary, secondary precipitates, mainly salt efflorescences were collected in order to represent the field variability, given rise to approximately 200 complex samples. The most powdery efflorescences were collected with plastic spatulas whereas the harder crusts were separated from the substrates with a stainless steel knife. Air temperature and relative humidity were measured in the field with a portable Hanna Instruments hygrometer, model HI8564.

The samples were stored in closed plastic vessels and transported to the laboratory soon after being collected, in order to prevent mineralogical changes. After that, the mineral precipitate samples were analyzed by X-ray powder diffraction (XRD). Morphological and compositional features were analyzed by scanning electron microscopy (SEM-EDS; images in secondary electrons - SE mode). Sample preparation and further details about analytical procedures have been described elsewhere (Valente and Leal Gomes, 2009).

\subsection{Water sampling and analysis}

Samples from affected rivers and from mine waters were collected during the same period. For river waters, in addition to the eight major rivers (Trimpancho, Cobica, Meca, Oraque, Olivargas, Odiel, Tinto, and Guadiamar), a small creek - Tintillo was also considered in order to cover the hydrochemical diversity associated with the drainage from the big Riotinto mine. In fact, both, Tinto and Tintillo receive contaminated drainage from this mining complex. It was not possible to collect water sample in Guadiamar River. So, values from the literature were used (Olías et al., 2005) for this river water. All water samples were filtered in the field through $0.45 \mu \mathrm{m}$ Millipore membranes into pre-cleaned, $100 \mathrm{~mL}$ HDPE sample bottles. The $\mathrm{pH}$, electrical conductivity (EC), and temperature of the water samples were measured in the field with multi parameter meter (CRISON MN). Before the measurement, electrodes were calibrated accurately, according to the manufacturer's instructions. Two samples of each site were taken for laboratory analyses: one for sulfate and other for total metals, REE, and arsenic. The sample for metals was acidified $(\mathrm{pH}<2)$ with $\mathrm{HNO}_{3}$ (65\% suprapur Merck). All samples were refrigerated immediately and stored at $4{ }^{\circ} \mathrm{C}$ until further analyses.

Concentrations of REE, metals and arsenic (e.g., $\mathrm{Al}, \mathrm{Fe}, \mathrm{Cu}, \mathrm{Zn}$ ) in water samples including rivers, mine waters, and extracts obtained by laboratory dissolution experiments of AMD-precipitates (described below in section 3.3), were determined by Inductively Coupled Plasma Mass Spectrometer (ICP-MS), at Actlabs 
Laboratory, Canada. The following isotopes of the REE were monitored in order to minimize isobaric interferences: ${ }^{139} \mathrm{La},{ }^{140} \mathrm{Ce},{ }^{141} \mathrm{Pr}$, ${ }^{146} \mathrm{Nd},{ }^{147} \mathrm{Sm},{ }^{153} \mathrm{Eu},{ }^{157} \mathrm{Gd},{ }^{159} \mathrm{~Tb},{ }^{163} \mathrm{Dy},{ }^{165} \mathrm{Ho},{ }^{166} \mathrm{Er},{ }^{169} \mathrm{Tm},{ }^{172} \mathrm{Yb}$, and ${ }^{175} \mathrm{Lu}$. External calibration curves were used $(0.1,2,10,100,250$, 500 , and $1000 \mathrm{ng} / \mathrm{kg}$ ) to quantify the REEs concentration in the samples. Sulfate was determined by turbidimetry, based on the Standard Methods 4500-E, considered appropriate for high range of sulfate concentrations. In this method, sulfate is precipitated with barium chloride so as to form barium sulfate crystals. Turbidity of the $\mathrm{BaSO}_{4}$ suspension was measured in NTU units (Nephelometric Turbidity Units) by using equipment NIGEL model and comparison of the readings with a standard curve.

\subsection{Laboratory dissolution experiments}

The dissolution of selected AMD-precipitates (total 48 samples) was simulated in the laboratory using natural samples in order to investigate controlling factors on REE fractionation during minerals uptake and release through rainfall episodes. A known mass of each mineral precipitate sample $(\sim 0.2 \mathrm{~g})$ was dissolved in $100 \mathrm{~mL}$ of ultra-pure water in batch reactors, at room temperature $\left(20^{\circ} \mathrm{C}\right)$ with constant agitation $(300 \mathrm{rpm})$. The experiments were performed for $10 \mathrm{~min}$ for each sample. At the end of the experiments, the supernatants were measured for $\mathrm{pH}$, electrical conductivity and total dissolved solids and then filtered through $0.45 \mu \mathrm{m}$ membrane. Each supernatant was divided into two subsamples in cleaned HDPE bottles, one for determination of sulfate and other for metals and REE (acidified with 65\% suprapure $\mathrm{HNO}_{3}$ ), and were stored in refrigerator until further analyses.

\section{Results}

\subsection{Mineralogy of AMD precipitates}

The mineralogical composition of the AMD-precipitates used in this study is presented in Table 1. Most of the samples are sulfate assemblages, except CO6 and RT14, which are pure goethite and melanterite, respectively. Details of the AMD-precipitates from the Iberian Pyrite Belt (SW, Spain) that are used in this study were described elsewhere (Valente et al., 2016a, 2016b). Illustration of AMD-precipitates present in some of the studied samples is shown in Fig. 2, comprising field images and morphological aspects observed in SEM-ES.

\subsection{Geochemistry of river water and AMD}

Most of the AMD samples (mine waters) have $\mathrm{pH}$ values between 1.8 and 3.4, and high concentration of sulfate (average of $73.7 \mathrm{~g} / \mathrm{L}$ ) (Table 2) and metals. Concentrations in river waters are considerably lower (except for Tintillo with $24.9 \mathrm{~g} / \mathrm{L}$ ). Metal and arsenic concentrations are provided in supplementary material (S1).

In the present study $\mathrm{Fe}, \mathrm{Cu}, \mathrm{Zn}$, and As show the highest concentrations in mine waters, with average values ranging between $110 \mathrm{mg} / \mathrm{L}$ for $\mathrm{Cu}$ and $17227 \mathrm{mg} / \mathrm{L}$ for Fe (Table S1). Aluminum (Al) and $\mathrm{Mg}$ have also relevant concentrations (average of $1688 \mathrm{mg} / \mathrm{L}$ and $1688 \mathrm{mg} / \mathrm{L}$ respectively). A special water sample, from a pond in Lagunazo mine was extremely acidic $(\mathrm{pH}=0.28)$ and highly concentrated for sulfates, arsenic, and some other elements $(\mathrm{Cu}$ and $\mathrm{Fe})$.

Concentrations of each REEs ( $\mathrm{La}$ to $\mathrm{Lu}$ ) in eight river waters ranged from $0.57 \mu \mathrm{g} / \mathrm{L}$ (obtained for Lu in Cobica River) to $2579 \mu \mathrm{g} / \mathrm{L}$ (Ce, in Trimpancho River). In the same way, total REE ( $\sum$ REE) concentrations in river water samples were also varied within wide range, from $297 \mu \mathrm{g} / \mathrm{L}$ (Cobica River) to $7032 \mu \mathrm{g} / \mathrm{L}$ (Trimpancho River) (Table 2).
Table 1

Mineralogical composition of the AMD-precipitate samples submitted to dissolution experiments. ${ }^{\mathrm{m}}$ - collected in mine sites; ${ }^{\mathrm{r}}-$ collected in the receiving rivers.

\begin{tabular}{|c|c|c|}
\hline Site & ID & Mineralogical assemblage \\
\hline \multirow[t]{2}{*}{${ }^{\mathrm{r}} \mathrm{COBICA}$} & $\mathrm{CO} 3$ & Hexahydrite + Pickeringite + Gypsum \\
\hline & $\mathrm{CO} 6$ & Goethite \\
\hline \multirow[t]{2}{*}{${ }^{\mathrm{r}}$ GUADIAMAR } & G2 & Copiapite + Alunogen + Halotrichite \\
\hline & G6 & Copiapite + Epsomite \\
\hline \multirow[t]{5}{*}{${ }^{\mathrm{m}}$ HERRERIAS } & HE1 & Epsomite + Melanterite \\
\hline & HE2 & Epsomite + Chalcanthite (tr)+Mallardite (tr) \\
\hline & HE3 & Hexahydrite + Gunningite + Alpersite + Gypsum \\
\hline & HE8 & Chalcanthite + Alpersite \\
\hline & HE14 & Hexaydrite + Pickeringite \\
\hline \multirow[t]{3}{*}{${ }^{\mathrm{m}}$ LAGUNAZO } & LZ1 & Melanterite + Alunogen + Gypsum \\
\hline & LZ3 & Magnesiocopiapite + Coquimbite + Mallardite $(\operatorname{tr})$ \\
\hline & LZ4 & Aluminocopiapite + Szomolnokite + Coquimbite \\
\hline \multirow[t]{3}{*}{ 'MECA } & ME1 & Epsomite + Pickeringite + Tamarugite \\
\hline & ME2 & Hexahydrite + Pickeringite \\
\hline & ME6 & Hexahydrite + Rozenite + Pickeringite \\
\hline${ }^{\mathrm{r}}$ ODIEL & OD8 & Hexahydrite + Alunogen + Pickeringite \\
\hline${ }^{\mathrm{r}}$ OLIVARGAS & OL2 & Copiapite + Hexahydrite + Pickeringite \\
\hline \multirow[t]{2}{*}{${ }^{\mathrm{r}}$ ORAQUE } & OR1 & Epsomite + Tamarugite + Gypsum + Pickeringite \\
\hline & OR5 & Epsomite + Pickeringite \\
\hline \multirow[t]{12}{*}{ mRIOTINTO } & RT11 & Magnesiocopiapite + Copiapite + Halotrichite \\
\hline & RT14 & Melanterite \\
\hline & RT16 & Rozenite + Boyleite \\
\hline & RT19 & Epsmite + Copiapite + Pickeringite \\
\hline & RT26 & Epsomite + Pickeringite-Halotrichite \\
\hline & RT28 & Epsomite + Gypsum + Jarosite \\
\hline & RT3 & Butlerite + Fibroferrite \\
\hline & RT34 & Epsomite-Hexahydrite + Magnesiocopiapite \\
\hline & RT35 & Melanterite + Copiapite + Halotrichite \\
\hline & RT36 & Rhomboclase + Szomolnokite + Coquimbite \\
\hline & RT40 & Copiapite + Coquimbite + Jarosite + Pickeringite \\
\hline & RT9 & Melanterite + Gypsum \\
\hline \multirow[t]{4}{*}{${ }^{\mathrm{m}}$ SAN TELMO } & ST3 & Chalcanthite + Hexahydrite + Alpersite \\
\hline & ST4 & Epsomite + Chalcanthite + Pickeringite $(\operatorname{tr})$ \\
\hline & ST6 & Hexahydrite + Pickeringite \\
\hline & ST10 & Epsomite + Pickeringite \\
\hline \multirow[t]{4}{*}{$\mathrm{m}_{\text {THARSIS }}$} & TH2 & $\begin{array}{l}\text { Szomolnokite }+ \text { Ferricopiapite }+ \text { Coquimbite } \\
+ \text { Halotrichite }\end{array}$ \\
\hline & TH3 & Szomolnokite + Ferricopiapite \\
\hline & TH4 & Szomolnokite + Ferricopiapite + Coquimbite \\
\hline & TH7 & Pickeringite + Halotrichite + Gypsum \\
\hline \multirow[t]{4}{*}{ r'TINTO RIVER } & TIR2 & Copiapite + Coquimbite + Hexahydrite + Jarosite \\
\hline & TIR4 & Magnesiocopiapite + Coquimbite \\
\hline & TIR5 & Ferricopiapite + Rhomboclase \\
\hline & TIR9 & Bieberite (?)+Mallardite \\
\hline \multirow[t]{5}{*}{ 'TRIMPANCHO } & TR1 & $\begin{array}{l}\text { Epsomite + Alunogen }+ \text { Tamarugite }+ \text { Pickeringite } \\
+ \text { Gypsum }\end{array}$ \\
\hline & TR10 & Hexahydrite + Tamarugite + Pickeringite \\
\hline & TR3 & Hexahydrite + Alunogen + Pickeringite + Gypsum \\
\hline & TR6 & Epsomite + Alunogen + Pickeringite + Gypsum \\
\hline & TR8 & Jarosite + Coquimbite $(\operatorname{tr})$ \\
\hline
\end{tabular}

As it is well known, the REEs are classified into three groups: LREE (La, Ce, Pr, and Nd), MREE (Eu, Gd, Tb, and Dy), and HREE (Er, Tm, Yb, and Lu) (Soyol-Erdene and Huh, 2013; Rollinson, 2014). For discussion convenience, the data for La, Gd, and Lu represent the three groups, respectively. REE concentrations in AMD and river water from IPB were normalized to North American Shale Composite (NASC) (Haskin et al., 1968; Gromet et al., 1984), and presented in Fig. 3. All samples showed MREE enrichment $\left(\mathrm{Gd}_{\mathrm{n}} /\right.$ $\mathrm{Lu}_{\mathrm{n}}=2.00-4.68$, Table 2) similarly to previously observed signature in acidic waters (Pérez-López et al., 2010). Most of the samples are asymmetrically enriched with HREE relative to LREE $\left(\mathrm{La}_{\mathrm{n}} /\right.$ $\mathrm{Lu}_{\mathrm{n}}=0.36-0.80$, except for Cobica River and Olivargas River $\left(\mathrm{La}_{\mathrm{n}} /\right.$ $\mathrm{Lu}_{\mathrm{n}}$ is 1.21 and 1.86 , respectively) (Table 2 and Fig. 3 ). The Cobica River (CO) (Fig. 3a) and Lagunazo Mine (LZ) (Fig. 3b) samples displayed negative anomaly for $\mathrm{Yb}$ in the NASC normalized pattern. 

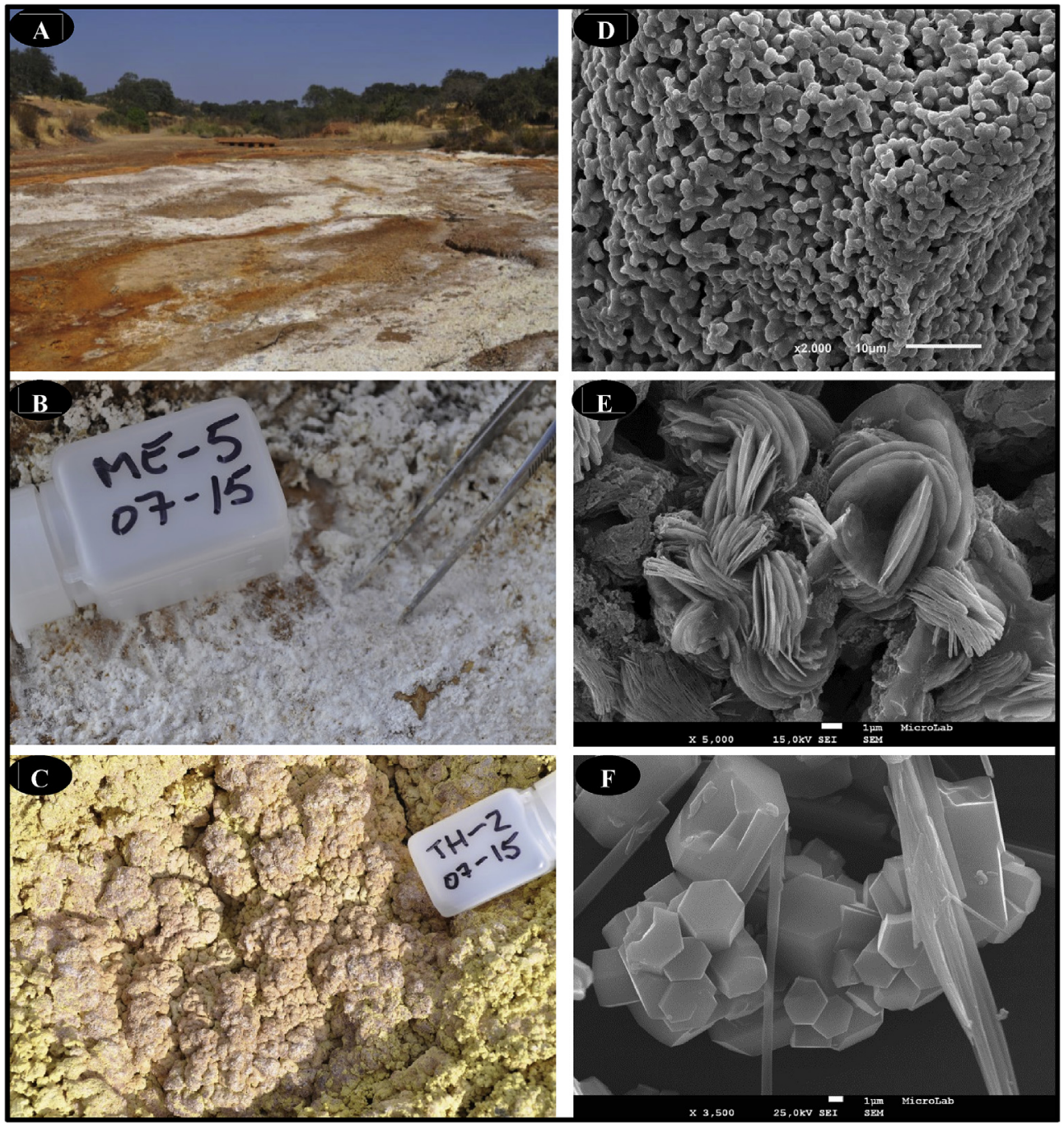

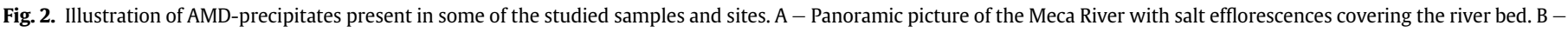

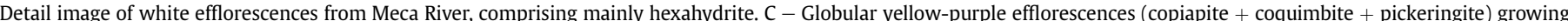

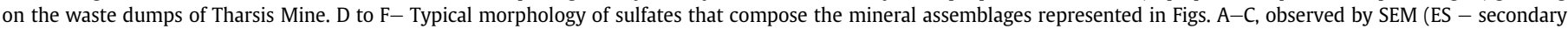

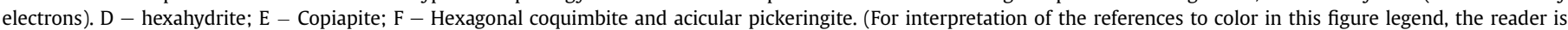
referred to the Web version of this article.)

\subsection{REE in mineral extracts}

Solutions obtained from laboratory dissolution experiments of AMD-precipitates show large variability on their geochemical behavior based on initial compositions of precipitates. Acidity for final solutions varied from strong acidic $(\mathrm{pH}=2.7$, for $\mathrm{G} 2$, TH4, TIR4, and TIR5) to weak acidic ( $\mathrm{pH}=5.2$, for HE2). The mineral samples were highly soluble, thus provided high electrical conductivity, up to $1698 \mu \mathrm{S} / \mathrm{cm}$ (TIR 5) with significant concentrations of metals (REE, Fe, $\mathrm{Cu}$, and $\mathrm{Mn}$ ) and sulfate in the solution (Table 3, Table S2). Only six samples (CO6, G6, RT40, TIR2, TIR9, and TR8), usually containing goethite/jarosite, copiapite, and coquimbite (Table 1), created more insoluble residues through the dissolution experiment and generated low electrical conductivity $(259-870 \mu \mathrm{S} / \mathrm{cm})$ in their extracts.

Individual concentrations of REE in extracts ranged between $0.0055 \mu \mathrm{g} / \mathrm{L}$ (Pr) and $337 \mu \mathrm{g} / \mathrm{L}$ (Ce) (Table S4) whereas total REE ( $\sum$ REE) were in the range of $1.27 \mu \mathrm{g} / \mathrm{L}$ (HE8) to $784.9 \mu \mathrm{g} / \mathrm{L}$ (OL2) with an average of $74.9 \mu \mathrm{g} / \mathrm{L}$ (Table 3 ).

REE concentrations in extract solutions are normalized to the
NASC (Haskin et al., 1968; Gromet et al., 1984) and presented in Fig. 4 a-b comparing that with water samples collected at the same sites. Precipitate extracts showed relative enrichment for MREE $\left(\mathrm{Gd}_{\mathrm{n}} / \mathrm{Lu}_{\mathrm{n}}=1.02-3.68, \mathrm{n}=37\right)$ in NASC normalized pattern excepting a few samples that are HREE enriched $\left(\mathrm{Gd}_{\mathrm{n}} /\right.$ $\mathrm{Lu}_{\mathrm{n}}=0.42-1.00, \mathrm{n}=11$ ). Additionally, most samples are asymmetrically enriched in HREE relative to LREE (for all, average $\mathrm{La}_{\mathrm{n}}$ / $\mathrm{Lu}_{\mathrm{n}}=0.49 \pm 0.44$, Table 3). Several samples (HE1, HE2, HE3, and HE8) displayed strong negative anomaly for $\mathrm{Ce}\left(\mathrm{Ce}^{*}=0.005-0.26\right)$, along with depletion for other LREE (La, Pr, Nd, and Sm, Fig. 4).

\section{Discussion}

\subsection{Properties of river waters and mine waters (AMD)}

The values of in situ parameters, particularly $\mathrm{pH}$, and of sulfate in mine waters indicate typical AMD conditions (Table 2). Also, metals (S1) are present in concentrations expected for AMD systems, in accordance with the literature (Grande, 2011). The high concentrations obtained for $\mathrm{Al}$ and $\mathrm{Mg}$ can be explained by the 
Table 2

Field parameters, total REE concentrations, and other selected variables for river and mine water samples.

\begin{tabular}{|c|c|c|c|c|c|c|c|c|c|c|c|}
\hline & ID & $\mathrm{pH}$ & $\mathrm{EC} \mathrm{mS} / \mathrm{cm}$ & TDS $(\mathrm{mg} / \mathrm{L})$ & $\mathrm{SO}_{4}^{2-} \mathrm{g} / \mathrm{L}$ & $\Sigma \mathrm{REE} \mu \mathrm{g} / \mathrm{L}$ & $\mathrm{La}_{\mathrm{n}} / \mathrm{Lu}_{\mathrm{n}}$ & $\mathrm{Gd}_{\mathrm{n}} / \mathrm{Lu}_{\mathrm{n}}$ & $\mathrm{Ce}^{*}$ & $\mathrm{Eu}^{*}$ & $\mathrm{Yb}^{*}$ \\
\hline \multicolumn{12}{|l|}{ River water } \\
\hline Tintillo & Tin & 2.3 & 14.6 & 9340 & 24.9 & 5806 & 0.38 & 2.01 & 1.10 & 0.83 & 1.01 \\
\hline Cobica & $\mathrm{CO}$ & 2.8 & 5.08 & 3250 & 2.56 & 297 & 1.21 & 3.26 & 0.99 & 0.83 & 0.61 \\
\hline Meca & $\mathrm{ME}$ & 2.7 & 4.44 & 2840 & 2.38 & 586 & 0.45 & 2.19 & 1.04 & 0.90 & 0.91 \\
\hline Odiel & OD & 3.4 & 1.87 & 1194 & 1.23 & 380 & 0.62 & 2.44 & 1.06 & 0.74 & 0.95 \\
\hline Olivargas & $\mathrm{OL}$ & 2.6 & 4.35 & 2780 & 5.12 & 3805 & 1.86 & 4.68 & 1.01 & 0.68 & 0.99 \\
\hline Oraque & OR & 2.5 & 2.66 & 1702 & 1.82 & 310 & 0.80 & 2.80 & 0.95 & 0.75 & 0.85 \\
\hline Trimpancho & TR & 1.8 & 31.8 & 20400 & 56.5 & 7032 & 0.79 & 2.78 & 1.02 & 0.90 & 0.94 \\
\hline Tinto & TIR & 2.5 & 9.09 & 5820 & 9.82 & 1528 & 0.36 & 2.00 & 0.97 & 0.76 & 0.95 \\
\hline Average & & 2.6 & 9.23 & 5916 & 13.0 & 2468 & 0.81 & 2.77 & 1.02 & 0.80 & 0.90 \\
\hline Stdev & & 0.4 & 10.0 & 6414 & 19.2 & 2723 & 0.51 & 0.89 & 0.05 & 0.08 & 0.13 \\
\hline Min & & 1.8 & 1.87 & 1194 & 1.23 & 297 & 0.36 & 2.00 & 0.95 & 0.68 & 0.61 \\
\hline Max & & 3.4 & 31.8 & 20400 & 56.5 & 7032 & 1.86 & 4.68 & 1.10 & 0.90 & 1.01 \\
\hline \multicolumn{12}{|l|}{ Mine water } \\
\hline Riotinto & RT & 1.8 & 16.2 & 10450 & 19.2 & 638 & 0.43 & 2.14 & 1.10 & 0.99 & 0.82 \\
\hline Tharsis & $\mathrm{TH}$ & 2.8 & 12.8 & 8170 & 20.9 & 5167 & 0.66 & 2.47 & 0.99 & 0.86 & 1.00 \\
\hline Lagunazo & $\mathrm{LZ}$ & 0.28 & 114 & 73200 & 181 & 2414 & 0.91 & 2.67 & 0.95 & 0.79 & 0.14 \\
\hline Average & & 1.6 & 65.3 & 30610 & 73.7 & 2739 & 0.67 & 2.43 & 1.01 & 0.88 & 0.65 \\
\hline Stdev & & 1.3 & 69.4 & 36910 & 92.9 & 2282 & 0.24 & 0.27 & 0.08 & 0.10 & 0.45 \\
\hline Min & & 0.28 & 16.2 & 8170 & 19.2 & 638 & 0.43 & 2.14 & 0.95 & 0.79 & 0.14 \\
\hline Max & & 2.8 & 114 & 73200 & 181 & 5167 & 0.91 & 2.67 & 1.10 & 0.99 & 1.00 \\
\hline
\end{tabular}

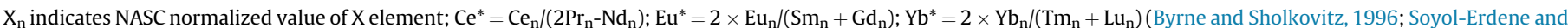
Huh, 2013).

dissolution of abundant felsic host rocks, enhanced by the strong acidity of the environment. Average concentrations of metals and arsenic are considerably lower in mine waters. Dilution and other natural attenuation processes may be contributing to these lower values. This is the case of precipitation and adsorption of trace
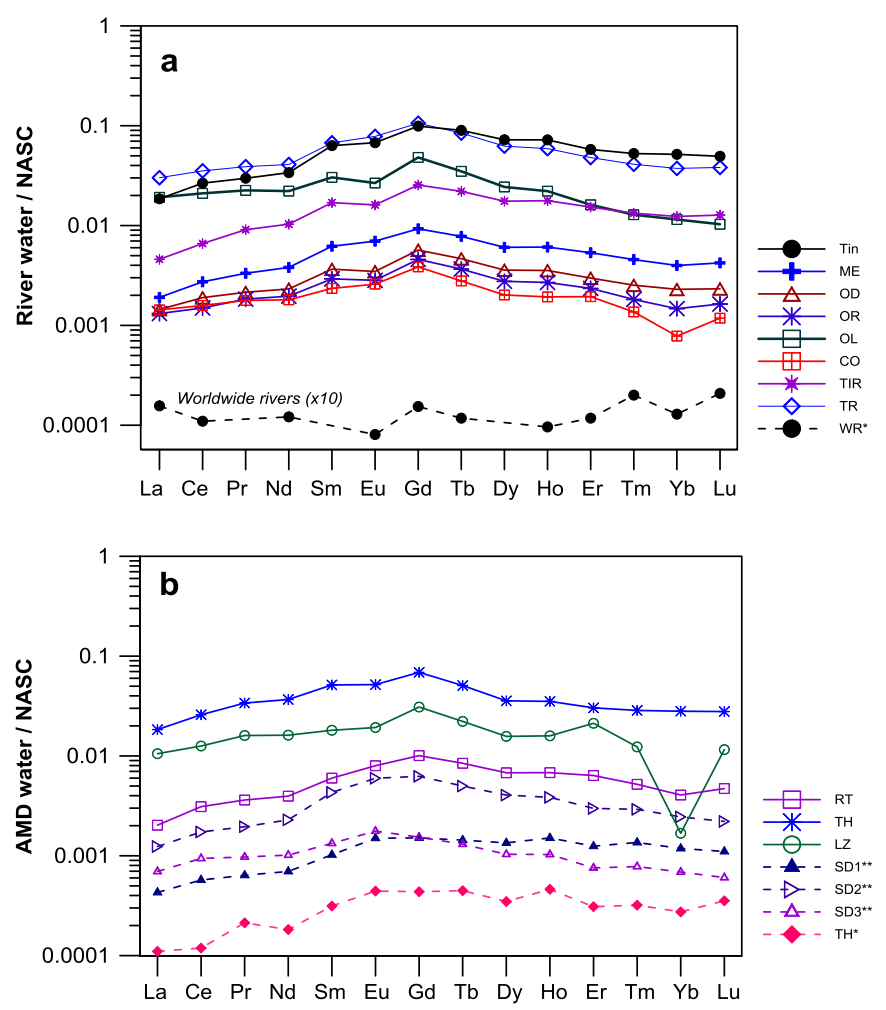

Fig. 3. NASC-normalized REE patterns for water samples. (a) River waters (this study, $\mathrm{n}=8$ ) comparing with worldwide rivers (WR*) average (Martin and Whitfield, 1983); (b) Acid mine drainage (this study, mine waters, $\mathrm{n}=3$ ) comparing with literature results of Tharsis mine $\left(\mathrm{TH}^{*}\right)$ (Fernández-Caliani et al., 2009) and São Domingos (SD**) (Elbaz-Poulichet and Dupuy, 1999). elements into iron oxyhydroxides, extensively observed in this type of systems (e.g., Sanchéz-España et al., 2005; Valente et al., 2013).

\subsection{REE in river waters and mine waters}

Dissolved $\sum$ REE concentrations were relatively high for IPB rivers $\left(\mathrm{n}=8\right.$ ) (Table 2 and Fig. 3 ) with factor by up to $10^{3}$ than worldwide riverine average (Martin and Whitfield, 1983; Goldstein and Jacobsen, 1988; Byrne and Sholkovitz, 1996; Leybourne and Johannesson, 2008). However, considering also the mine water samples $(\mathrm{n}=3)$, the results are normal for mining contexts (e.g., Ferreira da Silva et al., 2009).

Average of $\sum$ REE for river waters $(n=8,2468 \mu \mathrm{g} / \mathrm{L}$ ) (Table 2$)$ is higher than previously reported values from AMD affected rivers, such as Guadiamar (120-164 $\mu \mathrm{g} / \mathrm{L})$, Agrio $(127-210 \mu \mathrm{g} / \mathrm{L})$ (Olías et al., 2005), Tinto $(97.2 \pm 47.6 \mu \mathrm{g} / \mathrm{L})$, and Odiel River $(87.1 \pm 29.3 \mu \mathrm{g} / \mathrm{L})($ Elbaz-Poulichet and Dupuy, 1999). Additionally, total REE ( $\sum$ REE) concentrations in mine waters studied here were calculated as $638 \mu \mathrm{g} / \mathrm{L}$ (Riotinto), $5167 \mu \mathrm{g} / \mathrm{L}$ (Tharsis), and $2414 \mu \mathrm{g} / \mathrm{L}$ (Lagunazo) with an average $\sum$ REE of $2739 \mu \mathrm{g} / \mathrm{L}$ (Table 2). These values were also higher than that reported in other mines from IPB (118-372 $\mu \mathrm{g} / \mathrm{L}$ for São Domingos mine) (Pérez-López et al., 2010). Nevertheless, they are in the range of observed values from AMD samples, such as from Lousal mine, also in the IPB $(372-2846 \mu \mathrm{g} / \mathrm{L}$, $\mathrm{pH}=1.9-3.0$ ) (Ferreira da Silva et al., 2009), and Ronneburg uranium mining, Germany $(1600-3000 \mu \mathrm{g} / \mathrm{L}, \mathrm{pH}=2.77-3.55)$ (Merten et al., 2005).

When comparing the obtained results (Fig. 3) with literature (Fernández-Caliani et al., 2009), the NASC-normalized AMD contents for the samples TH, RT, and LZ are much higher than Tharsis mine $\left(\mathrm{TH}^{*}\right)$ and Sao Domingos mine (SD1** and SD3**) (sample references from the above citation). The leachate from the waste dumps of Tharsis mine is enriched in REE by two order of magnitude than that observed from AMD affected stream water near the same mine (Fernández-Caliani et al., 2009). The less pronounced enrichment of REE might be resulted from dilution of stream water.

In Table 2 and Fig. 3, NASC normalized REE pattern for most water samples, excluding Cobica River and Olivargas River, illustrated HREE enrichment relative to their LREE $\left(\mathrm{La}_{\mathrm{n}}\right)$ 
Table 3

Total REE concentrations and other selected variables for AMD-precipitate extracts.

\begin{tabular}{|c|c|c|c|c|c|c|c|c|c|c|}
\hline Sample ID & $\mathrm{pH}$ & $\mathrm{EC} \mu \mathrm{S} / \mathrm{cm}$ & TDS mg/L & $\mathrm{SO}_{4}^{2-} \mathrm{g} / \mathrm{L}$ & $\Sigma \mathrm{REE} \mu \mathrm{g} / \mathrm{L}$ & $\mathrm{La}_{\mathrm{n}} / \mathrm{Lu}_{\mathrm{n}}$ & $\mathrm{Gd}_{\mathrm{n}} / \mathrm{Lu}_{\mathrm{n}}$ & $\mathrm{Ce}^{*}$ & $\mathrm{Eu}^{*}$ & $\mathrm{Yb}^{*}$ \\
\hline $\mathrm{CO} 3$ & 4.0 & 1390 & 889 & 0.935 & 18.8 & 0.14 & 0.89 & 1.04 & 0.91 & 1.00 \\
\hline $\mathrm{CO} 6$ & 3.6 & 259 & 166 & 0.081 & 12.1 & 0.98 & 2.30 & 1.16 & 0.99 & 1.02 \\
\hline G2 & 2.7 & 1666 & 1066 & 1.18 & 63.9 & 1.45 & 2.10 & 1.26 & 0.87 & 1.03 \\
\hline G6 & 3.1 & 731 & 468 & 0.292 & 64.4 & 0.89 & 2.48 & 1.10 & 0.85 & 1.03 \\
\hline HE1 & 4.9 & 1295 & 829 & 1.04 & 18.4 & 0.04 & 1.57 & 0.05 & 1.14 & 0.94 \\
\hline HE14 & 4.2 & 1300 & 832 & 1.37 & 70.2 & 0.29 & 1.30 & 1.05 & 0.88 & 1.01 \\
\hline HE2 & 5.2 & 1362 & 872 & 0.916 & 118.5 & 0.02 & 0.79 & 0.005 & 1.10 & 0.95 \\
\hline HE3 & 5.0 & 1646 & 1054 & 1.36 & 93.5 & 0.0005 & 0.87 & 0.26 & 0.79 & 0.96 \\
\hline HE8 & 4.6 & 1384 & 886 & 0.984 & 1.27 & 0.24 & 0.72 & 0.05 & 0.81 & 0.40 \\
\hline LZ1 & 3.1 & 1418 & 907 & 0.861 & 24.0 & 1.46 & 2.23 & 1.13 & 0.89 & 1.00 \\
\hline LZ3 & 2.8 & 1621 & 1038 & 1.06 & 20.6 & 0.95 & 1.40 & 0.83 & 0.80 & 1.07 \\
\hline LZ4 & 2.9 & 1528 & 978 & 1.01 & 25.8 & 0.77 & 1.32 & 1.07 & 0.84 & 0.98 \\
\hline ME1 & 3.7 & 1294 & 828 & 1.04 & 35.2 & 0.14 & 0.71 & 0.98 & 0.98 & 1.02 \\
\hline ME2 & 4.0 & 1362 & 871 & 1.07 & 38.6 & 0.09 & 0.63 & 0.93 & 0.99 & 1.02 \\
\hline ME6 & 4.1 & 1395 & 893 & 1.11 & 123.2 & 0.12 & 1.29 & 1.20 & 0.86 & 1.00 \\
\hline OD8 & 4.4 & 1304 & 834 & 0.956 & 102.7 & 0.35 & 1.57 & 1.09 & 0.85 & 1.01 \\
\hline OL2 & 3.3 & 1504 & 963 & 1.00 & 784.9 & 1.43 & 2.92 & 1.15 & 0.95 & 1.02 \\
\hline OR1 & 4.0 & 1388 & 889 & 0.922 & 19.9 & 0.11 & 0.49 & 1.09 & 0.78 & 1.03 \\
\hline OR5 & 4.1 & 1234 & 790 & 0.863 & 65.3 & 0.42 & 1.32 & 1.11 & 0.83 & 1.00 \\
\hline RT11 & 2.8 & 1495 & 957 & 1.00 & 20.4 & 0.25 & 0.77 & 0.79 & 1.13 & 1.04 \\
\hline RT14 & 3.7 & 1278 & 818 & 0.850 & 18.2 & 0.52 & 1.99 & 1.26 & 1.05 & 1.01 \\
\hline RT16 & 3.3 & 1531 & 980 & 1.12 & 37.3 & 0.31 & 1.61 & 1.30 & 1.05 & 1.01 \\
\hline RT19 & 4.0 & 1133 & 725 & 0.896 & 96.0 & 0.20 & 1.27 & 1.21 & 0.85 & 1.03 \\
\hline RT26 & 4.1 & 1245 & 797 & 0.901 & 205.6 & 0.31 & 2.23 & 1.12 & 0.95 & 1.00 \\
\hline RT28 & 3.5 & 1009 & 645 & 0.615 & 123.0 & 0.20 & 1.25 & 1.01 & 0.98 & 1.01 \\
\hline RT3 & 2.8 & 1162 & 744 & 0.910 & 3.23 & 0.42 & 1.21 & 1.13 & 0.98 & 0.98 \\
\hline RT34 & 2.9 & 1602 & 1025 & 1.02 & 19.6 & 0.32 & 1.50 & 1.25 & 1.06 & 1.01 \\
\hline RT35 & 3.6 & 1343 & 859 & 0.892 & 22.9 & 0.33 & 1.49 & 1.28 & 1.07 & 1.02 \\
\hline RT36 & 3.5 & 1178 & 754 & 0.649 & 18.3 & 0.31 & 1.50 & 1.30 & 1.09 & 1.00 \\
\hline RT40 & 3.4 & 870 & 557 & 1.34 & 16.5 & 0.22 & 1.00 & 1.24 & 0.99 & 1.04 \\
\hline RT9 & 3.9 & 1221 & 781 & 0.854 & 22.1 & 0.49 & 2.03 & 1.19 & 0.85 & 0.96 \\
\hline ST3 & 3.4 & 1348 & 863 & 1.11 & 236.1 & 0.18 & 2.06 & 0.93 & 0.39 & 0.72 \\
\hline ST4 & 4.5 & 1329 & 851 & 0.985 & 92.8 & 0.17 & 1.66 & 1.13 & 0.44 & 0.80 \\
\hline ST6 & 4.5 & 1159 & 742 & 0.882 & 58.9 & 0.17 & 1.62 & 1.12 & 0.67 & 0.96 \\
\hline ST10 & 5.0 & 1383 & 885 & 0.959 & 61.4 & 1.46 & 1.99 & 0.91 & 1.08 & 1.34 \\
\hline TH2 & 2.8 & 1639 & 1049 & 1.17 & 22.2 & 1.03 & 1.94 & 1.14 & 1.20 & 1.07 \\
\hline TH3 & 2.8 & 1326 & 848 & 0.702 & 30.0 & 0.15 & 0.42 & 1.14 & 1.43 & 0.47 \\
\hline TH4 & 2.7 & 1617 & 1035 & 1.19 & 4.96 & 0.47 & 1.94 & 0.97 & 1.17 & 1.03 \\
\hline TH7 & 3.5 & 1289 & 786 & 1.06 & 181.7 & 0.54 & 1.64 & 1.22 & 1.01 & 1.03 \\
\hline TIR2 & 3.2 & 734 & 470 & 0.308 & 29.0 & 0.48 & 1.69 & 1.16 & 0.86 & 1.03 \\
\hline TIR4 & 2.7 & 1678 & 1074 & 1.14 & 15.8 & 0.34 & 1.48 & 1.08 & 0.92 & 1.02 \\
\hline TIR5 & 2.7 & 1698 & 1086 & 1.21 & 35.1 & 0.11 & 1.19 & 1.17 & 0.87 & 1.04 \\
\hline TIR9 & 3.9 & 786 & 503 & 0.514 & 22.6 & 0.30 & 0.94 & 0.96 & 0.87 & 1.04 \\
\hline TR1 & 3.2 & 1521 & 973 & 1.09 & 102.6 & 0.70 & 1.87 & 1.15 & 1.01 & 1.02 \\
\hline TR10 & 4.3 & 1388 & 888 & 1.03 & 66.4 & 0.07 & 1.02 & 1.10 & 0.94 & 1.02 \\
\hline TR3 & 3.2 & 1489 & 953 & 1.15 & 73.4 & 0.57 & 1.52 & 1.14 & 0.98 & 1.02 \\
\hline TR6 & 3.4 & 1422 & 919 & 1.07 & 247.1 & 1.85 & 3.68 & 1.37 & 1.07 & 1.03 \\
\hline TR8 & 3.6 & 302 & 194 & 0.057 & 12.9 & 1.01 & 1.88 & 1.31 & 1.00 & 1.02 \\
\hline Average & 3.6 & 1297 & 829 & 0.932 & 74.9 & 0.49 & 1.53 & 1.03 & 0.94 & 0.98 \\
\hline Stdev & 0.7 & 315 & 202 & 0.287 & 120 & 0.45 & 0.63 & 0.31 & 0.17 & 0.14 \\
\hline Min & 2.7 & 259 & 166 & 0.057 & 1.27 & 0.0005 & 0.42 & 0.005 & 0.39 & 0.40 \\
\hline Max & 5.2 & 1698 & 1086 & 1.37 & 784.9 & 1.85 & 3.68 & 1.37 & 1.43 & 1.34 \\
\hline
\end{tabular}

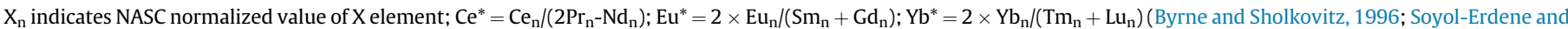
Huh, 2013).

$\left.\mathrm{Lu}_{\mathrm{n}}=0.36-0.80\right)$. Not all samples show relevant Ce anomaly $\left(\mathrm{Ce}^{*}=0.93 \pm 0.06\right)$ and several samples (LZ, CO, OR, and RT) are displaying considerable negative anomaly for $\mathrm{Yb}\left(\mathrm{Yb}^{*}=0.14-0.85\right)$. In these last cases, and according to the available data, $\mathrm{Yb}$ is being probably retained by AMD-precipitates, as it observed for $\mathrm{CO}$ and $\mathrm{LZ}$ in Fig. 4.

Lagunazo Mine (LZ) is a special sampling point, since it receives water from waste dumps with extremely low $\mathrm{pH}$ values $(0.28)$. Such acidic conditions, associated with the presence of pyrite ashes, may be affecting the typical dissolution-precipitation processes as well as governing the mechanisms of adsorption or incorporation of $\mathrm{Yb}$ into the newly formed salts. It seems that such anomalous conditions favor incorporation into the AMD-precipitates. This assumption seems to be confirmed by the regional trend. In fact, the Cobica River (CO) receives water from Lagunazo mine, justifying the similar behavior observed for both water samples ( $\mathrm{LZ}$ and $\mathrm{CO}$ ) (Fig. 3). In Cobica River, the Yb anomaly could be less pronounced because this river also receives water from other mines, such as Herrerías.

In AMD affected rivers, significant amount of REE is released to the aquatic system and then co-precipitate with secondary minerals in result of evaporation in dry weather. Therefore, the seasonal variation including processes of evaporation (during summer) and dissolution (during winter) may play a major role in the redistribution of REE. The NASC-normalized REE patterns presumably illustrate fractionation within the series in relation with the composition and crystalline structures of the secondary precipitates.

MREE and asymmetric HREE enrichment of the NASC normalized pattern of acid waters is still not well explained and results are 

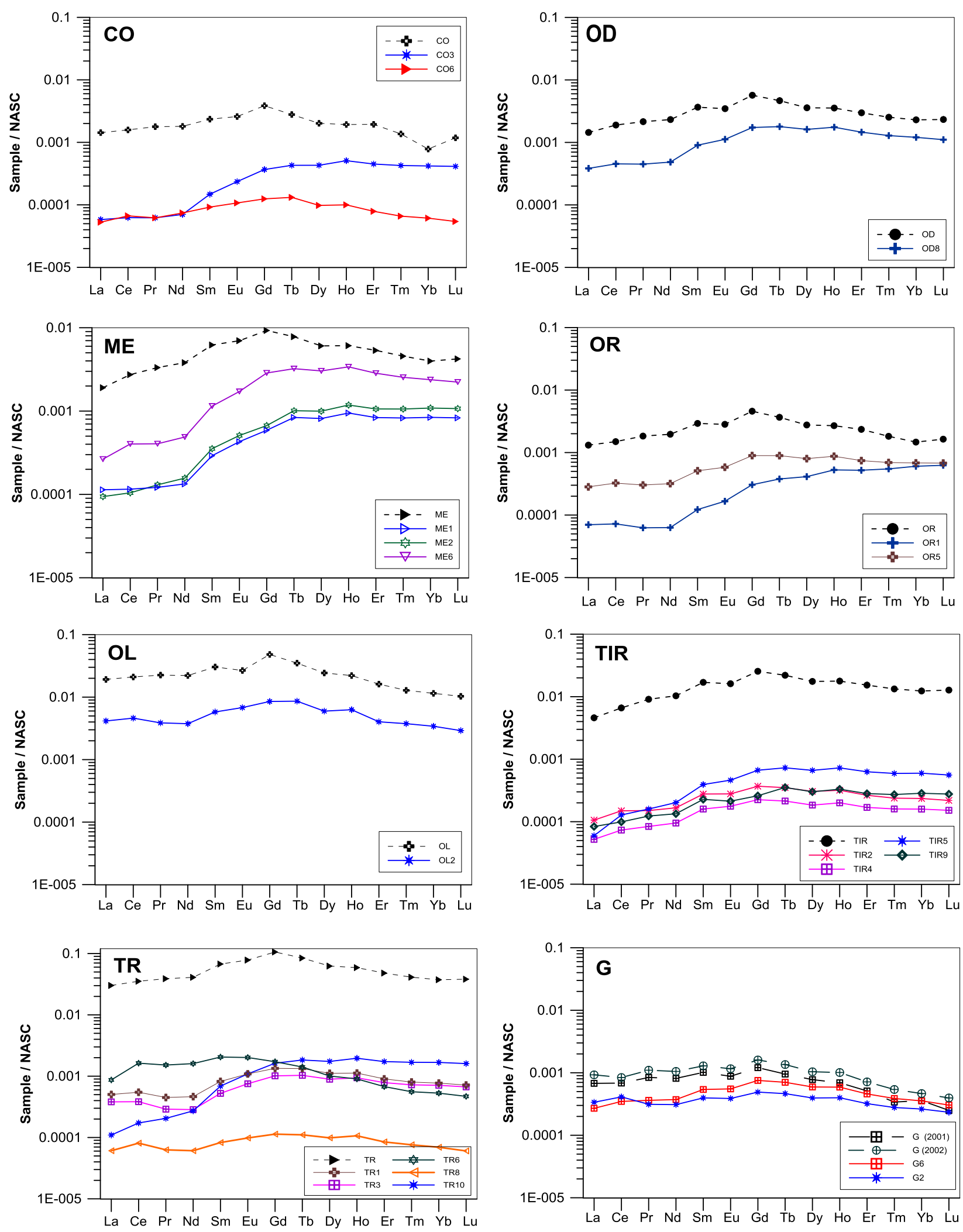

a

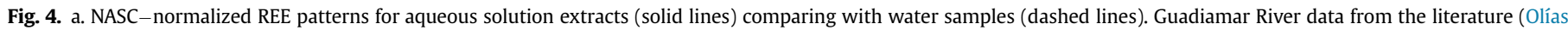
et al., 2005). b. NASC-normalized REE patterns for aqueous solution extracts (solid lines) comparing with water samples (dashed lines). 

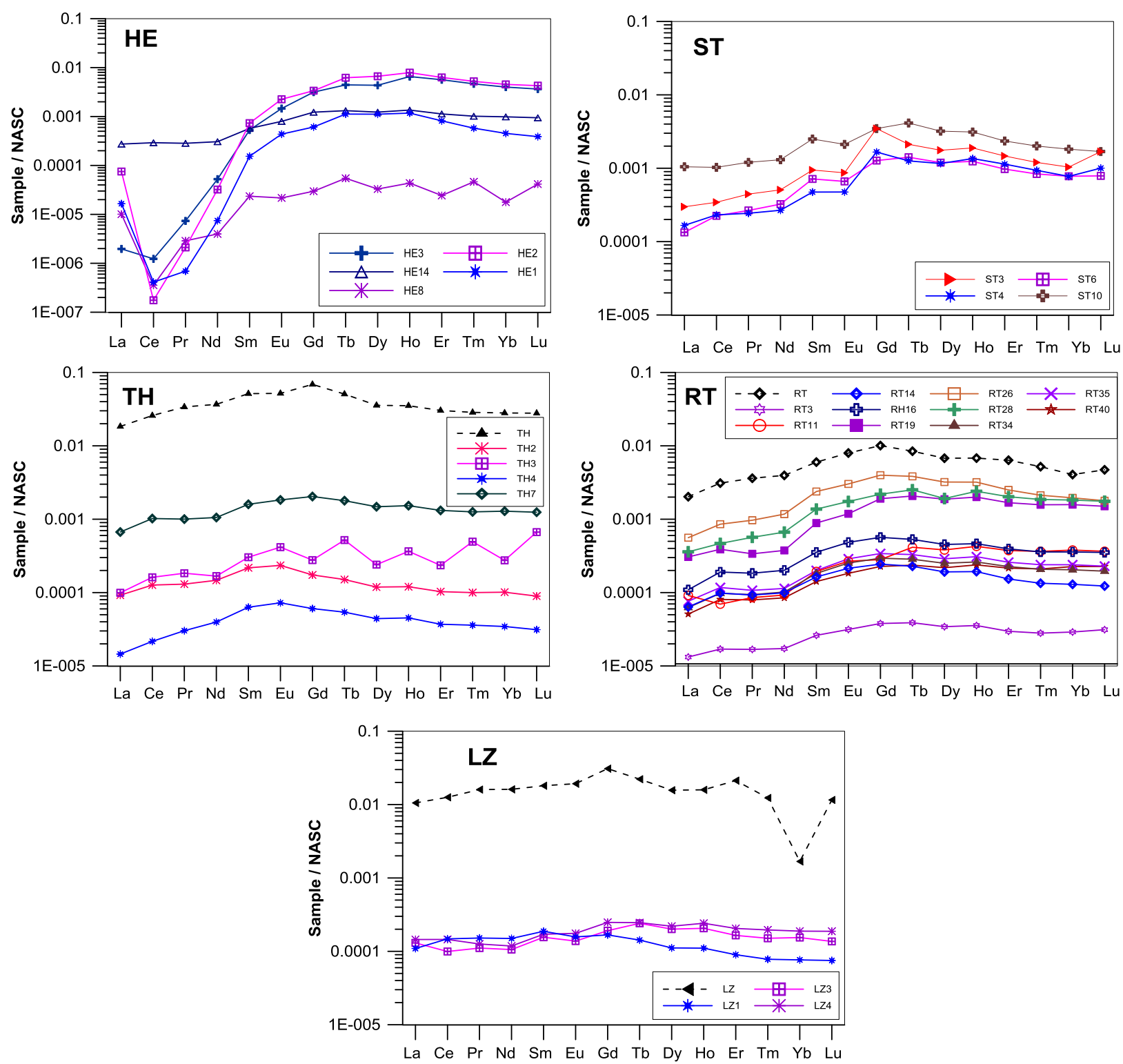

b

Fig. 4. (continued)

sometimes contradictory. Some authors suggested that it is due to preferential release of HREE from the solution by Fe oxyhydroxides (Olías et al., 2005), but other authors have considered a preferential adsorption of the LREE relative to oxyhydroxides (Elderfield et al., 1990). Moreover, some secondary minerals, such as jarosite, preferentially incorporate LREE rather than MREE and HREE, but it generates MREE enriched pattern when reacted with slightly acidic solutions (Welch et al., 2009). An interesting finding of the present study was the LREE enrichment relative to HREE observed in samples with aluminum sulfates. This is an exception to the general behavior observed in the NASC normalized REE patterns, highlighting the key role of Al-sulfates, namely pickeringite, for REE retention. Through the facts, fractionation within the REE series can be generally reasoned by results of liquid-solid interactions at the different environmental conditions.

\subsection{REE fractionation during mineral dissolution}

Since water bodies affected by AMD have unique signatures for both of NASC normalized pattern and concentration of REE (Merten et al., 2005), mineral precipitation and re-dissolution under seasonal variation conditions can control REE mobility and fractionation within the series.

It is worth mentioning that low crystalline phases, such as schwertmannite and basaluminite, known by their retention ability, were not observed in any mineralogical assemblage (Table 1). However they are typical AMD-precipitates, and already identified in other works in the IPB (Ayora et al., 2015; Sánchez-España et al., 2005). The strong aridity and the absence of dilution conditions in the sampling period (July) may justify the absence of these phases. Instead, there is the iron oxyhydroxide goethite, for example in 
sample CO6. This sample, composed by pure goethite, has lower concentrations from Sm to Lu than CO3. In fact, this last presents a simple assemblage typically observed in the IPB rivers during summer (Valente et al., 2016a), dominated by magnesium and aluminum sulfates. Hence, the iron oxyhydroxide seems less efficient than the sulfates in the retention of these REE. Likewise, the assemblage composed by butlerite + fibroferrite (RT3) shows the lowest concentrations, suggesting that these iron sulfates have lower ability for REE retention than the magnesium and aluminum sulfates (for example RT26, RT28, and RT19) (Table 1).

The extracts from Herrerias mine (HE) show different REE patterns, which can be explained by the different source of the samples. HE14 has a pattern similar to the river waters, which is in accordance with its sampling in a small creek that receives AMD from different waste dumps inside the Herrerías complex. On the other hand, HE1, HE2, HE3, and HE8 represent a singular mining space. These four samples display the most negative Ce anomalies of the studied samples. Also, they show very high concentrations of $\mathrm{Cu}$ and $\mathrm{Mg}$. This behavior can be related with special redox conditions of the sampling site, since they were located under a covering plastic of an artificial pond for the collection of acid waters. Likewise, the lithology of the materials that are under the plastic could also affect the processes of neoformation when dealing with wastes coming from different sources (including from $\mathrm{Cu}$-rich paragenesis) and also with a grain size much smaller than that of the waste dumps (silt and fine sand). Moreover, this pond received tailings from the treatment plant, which implies the presence of other substances used in flotation (xanthates, cyanides, sparkling, collectors, etc). Further investigation must be carried out to assess the influence of these factors on REE fractionation.

San Telmo Mine is the only studied site with abundant copper sulfates. Specifically, ST3 is the most chalcanthite enriched sample. Taken in consideration this mineralogical singularity, one may hypothesize that chalcanthite could be responsible for the Gd anomaly.

Samples from Guadiamar (G1 and G2) show similar REE pattern. Such a behavior is probably controlled by the common presence of copiapite. In turn, in Meca samples (ME), the observed trend could be attributed to the magnesium and aluminum sulfates. So, in the present study, the highest retention of REE occurs in samples enriched in magnesium (epsomite or hexahydrite) and aluminum sulfates, mainly pickeringite.

\section{Conclusions}

It is possible to assess that forming and dissolution of mineral precipitates in acid mine drainage have significant contribution on REE distribution in acidic waters. AMD and river water samples as well as water extracts of the AMD-precipitates reveal the enrichment of MREE in their NASC normalized pattern. Moreover, in most cases, the mineral precipitates retain HREE relative to LREE. As observed in other mining regions, relevant negative anomalies for Ce were observed for some mineral extracts and were presumably controlled by mineralogical composition. In highly acidic environments, Yb showed unique negative anomaly in aquatic phase, probably due to preferential incorporation into the solid phases.

The highest retention of REE occurs in samples enriched in magnesium (epsomite or hexahydrite) and aluminum sulfates, mainly pickeringite, probably reflecting the absence of other low crystalline fixing phases, like schwertmannite. However, further investigations are required in order to explain the reason of different extensions of MREE enrichment and other REE anomalies in acidic mine affected environments.

\section{Acknowledgements}

Financial support was provided by the Andalusian Autonomous Government Excellence Project, code P06-RNM-02167. This work was also co-funded by the European Union through the European Regional Development Fund, based on COMPETE 2020, project ICT (UID/GEO/04683/2013), reference POCI-01-0145-FEDER-007690, national funds provided by FCT. Post-Doctoral Fellowship through Erasmus Mundus SAT program and Young Scientist Research Grant (SEAS-2015-14) of the National University of Mongolia were supported for T.-O. Soyol-Erdene. The authors also appreciate the valuable comments and suggestions made by the anonymous reviewers.

\section{Appendix A. Supplementary data}

Supplementary data related to this article can be found at https://doi.org/10.1016/j.chemosphere.2018.04.095.

\section{References}

Ayora, C., Torres, E., Lozano, A., Macías, F., Carrero, S., Pérez-López, R., Nieto, J.M., 2015. Acid Mine Drainage: a Possible Source of Rare Earth Elements, Goldschmidt 2015. Abstract 153.

Antunes, J.F., Azevedo, M.R., Mendes, M.H., Ribeiro, S., 2010. New petrographic geochemical and geochronological data for the Reguengos de Monsaraz pluton (Ossa Morena, SW Iberian Massif, Portugal). Estud. Geol. 66 (1), 25-34.

Byrne, R.H., Sholkovitz, E.R., 1996. Chapter 158 Marine Chemistry and Geochemistry of the Lanthanides. Handbook on the Physics and Chemistry of Rare Earths. Elsevier, pp. 497-593.

Conde, C., Tornos, F., Large, R., Danyushevsky, L., Solomon, M., 2009. Análisis de elementos traza por la LA-ICPMS en pirita de los sulfuros masivos de Tharsis (FPI). Macla 11, 63-64.

Elbaz-Poulichet, F., Dupuy, C., 1999. Behaviour of rare earth elements at the freshwater-seawater interface of two acid mine rivers: the Tinto and Odiel (Andalucia, Spain). Appl. Geochem. 14 (8), 1063-1072.

Elderfield, H., Upstill-Goddard, R., Sholkovitz, E.R., 1990. The rare earth elements in rivers, estuaries, and coastal seas and their significance to the composition of ocean waters. Geochem. Cosmochim. Acta 54 (4), 971-991.

Fernández-Caliani, J., Barba-Brioso, C., De la Rosa, J., 2009. Mobility and speciation of rare earth elements in acid minesoils and geochemical implications for river waters in the southwestern Iberian margin. Geoderma 149 (3), 393-401.

Ferreira da Silva, E., Bobos, I., Xavier Matos, J., Patinha, C., Reis, A.P., Cardoso Fonseca, E., 2009. Mineralogy and geochemistry of trace elements and REE in volcanic massive sulfide host rocks, stream sediments, stream water and acid mine drainage from the Lousal mine area (Iberian Pyrite Belt, Portugal). Appl. Geochem. 24, 383-401.

García de Miguel, J., 1990. Mineralogía, paragénesis y sucesión de los sulfuros masivos de la Faja Pirítica en el suroeste de la Península Ibérica. Bol. Geol. Min. 101 (1), 73-105.

Goldstein, S.J., Jacobsen, S.B., 1988. Rare earth elements in river waters. Earth Planet Sci. Lett. 89 (1), 35-47.

Grande, J.A., 2011. Impact of AMD processes on the public water supply: hydrochemical variations and application of a classification model to a river in the Iberian Pyritic Belt S.W. Spain. Hydrol. Res. 42 (6), 472-478.

Grande, J., Santisteban, M., De la Torre, M., Valente, T., Pérez-Ostalé, E., 2013. Characterisation of AMD pollution in the reservoirs of the Iberian pyrite Belt. Mine Water Environ. 32 (4), 321-330.

Grawunder, A., Merten, D., Büchel, G., 2014. Origin of middle rare earth element enrichment in acid mine drainage-impacted areas. Environ. Sci. Pollut. Res. 21 (11), 6812-6823.

Gromet, L.P., Haskin, L.A., Korotev, R.L., Dymek, R.F., 1984. The "North American shale composite": its compilation, major and trace element characteristics. Geochem. Cosmochim. Acta 48 (12), 2469-2482.

Haskin, L., Wildeman, T., Haskin, M., 1968. An accurate procedure for the determination of the rare earths by neutron activation. J. Radioanal. Chem. 1 (4), $337-348$.

Lecomte, K.L., Sarmiento, A.M., Borrego, J., Nieto, J.M., 2017. Rare earth elements mobility processes in an AMD-affected estuary: Huelva Estuary (SW Spain). Mar. Pollut. Bull. 121, 282-291.

Leybourne, M.I., Johannesson, K.H., 2008. Rare earth elements (REE) and yttrium in stream waters, stream sediments, and $\mathrm{Fe}-\mathrm{Mn}$ oxyhydroxides: fractionation, speciation, and controls over REE $+\mathrm{Y}$ patterns in the surface environment. Geochem. Cosmochim. Acta 72 (24), 5962-5983.

López-González, N., Borrego, J., Carro, B., Grande, J.A., de la Torre, M.L., Valente, T., 2012. Rare earth-element fractionation patterns in estuarine sediments as a consequence of acid mine drainage: a case study in SW Spain. Bol. Geol. Min. 123 (1), 55-64. 
Mantero, E.M., Alonso-Chaves, F.M., García-Navarro, E., Azor, A., 2011. Tectonic style and structural analysis of the Puebla de Guzmán Antiform (Iberian Pyrite Belt, South Portuguese Zone, SW Spain). Geol. Soc. Lond. Special Publ. 349 (1), 203-222.

Martin, J.-M., Whitfield, M., 1983. The Significance of the River Input of Chemical Elements to the Ocean, Trace Metals in Sea Water. Springer, pp. 265-296.

Merten, D., Geletneky, J., Bergmann, H., Haferburg, G., Kothe, E., Büchel, G., 2005. Rare earth element patterns: a tool for understanding processes in remediation of acid mine drainage. Chem. der Erde - Geochem. 65 (Suppl. 1), 97-114.

Migaszewski, Z.M., Galuszca, A., 2015. The characteristics, occurrence, and geochemical behavior of rare earth elements in the environment: a review. Crit. Rev. Environ. Sci. Technol. 45, 429-471.

Migaszewski, Z.M., Galuszca, A., Dolegowska, S., 2016. Rare earth and trace element signatures for assessing an impact of rock mining and processing on the environment: Wísniówka case study, south-central Poland. Environ. Sci. Pollut. Res. 23, 24943-24959.

Nordstrom, D.K., 2011. Hydrogeochemical processes governing the origin, transport and fate of major and trace elements from mine wastes and mineralized rock to surface waters. Appl. Geochem. 26, 1777-1791.

Olías, M., Cerón, J.C., Fernández, I., De la Rosa, J., 2005. Distribution of rare earth elements in an alluvial aquifer affected by acid mine drainage: the Guadiamar aquifer (SW Spain). Environ. Pollut. 135 (1), 53-64.

Ostale, E., 2014. Caracterización ambiental de estructuras mineras en la Faja Pirític Ibérica como soporte metodológico de gestión territorial. PhD thesis. Universidad de Huelva, p. 329 (abstract in English).

Pérez-López, R., Delgado, J., Nieto, J.M., Márquez-García, B., 2010. Rare earth element geochemistry of sulphide weathering in the São Domingos mine area (Iberian Pyrite Belt): a proxy for fluid-rock interaction and ancient mining pollution. Chem. Geol. 276 (1-2), 29-40.

Prudêncio, M.I., Valente, T., Marques, R., Braga, Sequeira, 2015. Geochemistry of rare earth elements in a passive treatment system built for acid mine drainage remediation. Chemosphere 138, 691-700.

Rollinson, H.R., 2014. Using Geochemical Data: Evaluation, Presentation, Interpretation. Routledge.

Sáez, R., Pascual, E., Toscano, M., Almodóvar, G., 1999. The Iberian type of volcano- sedimentary massive sulphide deposits. Miner. Deposita 34 (5), 549-570.

Sánchez-España, J., Velasco, F., Yusta, I., 2000. Hydrothermal alteration of felsic volcanic rocks associated with massive sulphide deposition in the northern Iberian Pyrite Belt (SW Spain). Appl. Geochem. 15 (9), 1265-1290.

Sanchéz-España, J., López Pamo, E., Santofimia, E., Aduvire, O., Reyes, J., Barettino, D. 2005. Acid mine drainage in the Iberian Pyrite Belt (Odiel river watershed, Huelva, SW Spain): geochemistry, mineralogy and environmental implications. Appl. Geochem. 20, 1320-1356.

Soyol-Erdene, T.-O., Huh, Y., 2013. Rare earth element cycling in the pore waters of the Bering Sea Slope (IODP Exp. 323). Chem. Geol. 358, 75-89.

Tornos, F., Solomon, M., Conde, C., Spiro, B.F., 2008. Formation of the Tharsis massive sulfide deposit, Iberian Pyrite Belt: geological, lithogeochemical, and stable isotope evidence for deposition in a brine pool. Econ. Geol. 103 (1), 185-214.

Valente, T., Grande, J., De La Torre, M., Santisteban, M., Cerón, J., 2013. Mineralogy and environmental relevance of AMD-precipitates from the Tharsis mines, Iberian pyrite Belt (SW, Spain). Appl. Geochem. 39, 11-25.

Valente, T.M., Leal Gomes, C., 2009. Occurrence, properties and pollution potential of environmental minerals in acid mine drainage. Sci. Total Environ. 407 (3), 1135-1152.

Valente, T.M.F., Grande, J.A., De la Torre, M.L., 2016a. Magnesium and aluminum sulfates in salt efflorescences from acid mine drainage in the Iberian Pyrite Belt (SW Spain). Proc. IMWA 2016, 445-450.

Valente, T.M.F., Grande, J.A., De la Torre, M.L., 2016b. Typical secondary mineralogical assemblages from acid mine drainage systems in the Iberian pyrite Belt (SW Spain). In: Proceedings of 2nd International Congress on the Management of Mining Wastes and Post-Mining, Marrakesh, pp. 153-156.

Velasco, F., Sánchez-España, J., Boyce, A., Fallick, A., Sáez, R., Almodóvar, G., 1998. A new sulphur isotopic study of some Iberian Pyrite Belt deposits: evidence of a textural control on sulphur isotope composition. Miner. Deposita 34 (1), 4-18.

Verplanck, P.L., Antweiler, R.C., Nordstrom, D.K., Taylor, H.E., 2001. Standard reference water samples for rare earth element determinations. Appl. Geochem. 16, $231-244$.

Welch, S.A., Christy, A.G., Isaacson, L., Kirste, D., 2009. Mineralogical control of rare earth elements in acid sulfate soils. Geochem. Cosmochim. Acta 73 (1), 44-64. 